EUROPEAN SECURITY IN A POST-BREXIT WORLD 


\section{BREXIT STUDIES SERIES}

Series Editors: Alex De Ruyter, Jon Yorke and Haydn Davies, Centre for Brexit Studies, Birmingham City University, UK

With the vote on 23 June 2016 for the UK to leave the European Union, it has become imperative for individuals, business, government and the wider society to understand the implications of the referendum result. This series, published in collaboration with the Centre for Brexit Studies at Birmingham City University, UK, examines a broad sweep of topics related to Brexit. It aims to bring together academics from across the disciplines to confront and examine the challenges withdrawal from the EU brings. The series promotes rigorous engagement with the multifaceted aspects of both the 'leave' and 'remain' perspectives in order to enhance understanding of the consequences for the UK, and for its relationship with the wider world, of Brexit, and aims to suggest measures to counter the challenges faced.

\section{Published Titles}

Alex De Ruyter and Beverley Nielsen, Brexit Negotiations after Article 50: Assessing Process, Progress and Impact

David Hearne and Alex de Ruyter, Regional Success after Brexit: The Need for New Measures

\section{Forthcoming Titles}

Arantza Gomez Arana, Brexit and Gibraltar: The Negotiations of a Historically Contentious Region 


\section{PRAISE FOR EUROPEAN SECURITY IN A POST-BREXIT WORLD}

'Superficially, Brexit looks quite straightforward; but, dig only a little deeper and the complexities are quickly evident. This is particularly so for the security sector. This book is an important and timely contribution to the debate and the need for specialists and wider public alike to have steady, informed hands guide them through the maze. The authors take the reader carefully through a phased introduction to these complexities and provide a detailed explanation of the respective legal and agency components of the intelligence/law enforcement sectors. One of the "stand-out" features of this book is that it is able to present the reader with a clear understanding in a straightforward and accessible reader-friendly style of what are highly complex, often highly nuanced elements'.

Professor Neil Renwick, Coventry University, UK 
This page intentionally left blank 


\title{
EUROPEAN SECURITY IN A POST-BREXIT WORLD
}

\author{
STEFANIA PALADINI \\ Birmingham City University, UK \\ AND \\ IGNAZIO CASTELLUCCI \\ University of Teramo, Italy
}

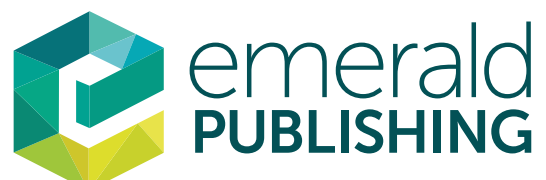

United Kingdom - North America - Japan - India Malaysia - China 
Emerald Publishing Limited

Howard House, Wagon Lane, Bingley BD16 1WA, UK

First edition 2019

Copyright (C) Stefania Paladini and Ignazio Castellucci, 2019. Published under an exclusive licence.

Reprints and permissions service

Contact: permissions@emeraldinsight.com

No part of this book may be reproduced, stored in a retrieval system, transmitted in any form or by any means electronic, mechanical, photocopying, recording or otherwise without either the prior written permission of the publisher or a licence permitting restricted copying issued in the UK by The Copyright Licensing Agency and in the USA by The Copyright Clearance Center. No responsibility is accepted for the accuracy of information contained in the text, illustrations or advertisements. The opinions expressed in these chapters are not necessarily those of the Author or the publisher.

British Library Cataloguing in Publication Data

A catalogue record for this book is available from the British Library

ISBN: 978-1-78769-840-6 (Print)

ISBN: 978-1-78769-837-6 (E-ISBN)

ISBN: 978-1-78769-839-0 (Epub)

Information and analyses included in this book are based on data as available as of July 2019.

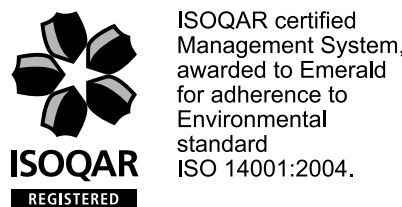

Certificate Number 1985

ISO 14001

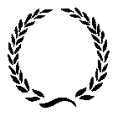




\section{CONTENTS}

List of Tables and Figures

1. Introduction

1

2. Legal Framework of EU Security and Law Enforcement

3. The EU Agencies and Other European

Security-related Institutions and Arrangements

4. What Lies Ahead? A Post-Brexit Scenario Analysis

References 


\section{LIST OF TABLES AND FIGURES}

\section{Tables}

Table 3. 1. The EU Security Framework. 60

\section{Figures}

Fig. 3.1. European External Action Service (EEAS) Organisation Chart. 


\section{1 \\ INTRODUCTION}

\subsection{INTELLIGENCE COOPERATION, INFORMATION SHARING AND LAW ENFORCEMENT IN A POST-BREXIT EUROPE}

If the most of the major topics of discussion about Brexit are controversial and rich in contrasting views, only a few of them display the level of complexity found in the areas of security, here intended as including 'defence', 'intelligence' and 'lawenforcement'. Since the announcement of the referendum results in June 2016, the question that has occupied the most the political debate on European security is the one about the degree to which the UK is going to be damaged, if at all, by leaving the European Union (EU) and, therefore, what it carries in terms

of participation to EU agencies and access rights to the existing legal, institutional framework and technical instruments.

This is well exemplified by two contrasting statements.

Sir David Omand, a former head of GCHQ, quoted in Independence Daily, declared that the UK will lose from Brexit.

We are part of an established information-sharing network with our partners whilst still retaining 
control of our border. The best of both worlds. Why jeopardise the flow of information we receive? (Omand, as quoted by Independence Daily, 16 April 2016).

On the other hand, another senior intelligence officer, Sir Richard Dearlove, a former head of MI6, believes that Brexit would not damage the UK security. 'The truth about Brexit from a national security perspective is that the cost to Britain would be low', Dearlove says.

Brexit would bring two potentially important security gains: the ability to dump the European Convention on Human Rights - remember the difficulty of extraditing the extremist Abu Hamza of the Finsbury Park Mosque - and, more importantly, greater control over immigration from the European Union. (Dearlove, as quoted by Independence Daily, 16 April 2016).

Both these statements are correct, and this should not come as a surprise, as they address two selected, different aspects of the security discourse. On the one hand, appreciation is shown for established networks and cooperative instruments that have proved to work remarkably well. On the other hand, a more traditional approach is displayed in relation to the needs of a sector - intelligence and national security - quintessentially sovereign and national, and still legally so according to article 4(2) of the Treaty on European Union (TEU): an area of international relations where integration tends to remain relatively low, although cooperation and information sharing do occur.

The old saying of intelligence that 'there are friendly countries, but do not exist friendly intelligence agencies' holds true even in present times. However, it is a fact that the EU's security as a whole strongly relies on the Member state(s)' 
willingness and capability to work together, share information and cooperate on issues of common interests - especially in counterterrorism and prevention of international crime. In this respect, the central role played by the UK, thus far, is also factually undeniable. There are no doubts that the EU security environment is going to change after Brexit: whilst the consequences are going to be particularly relevant for the UK, a certain impact will also be felt in the EU. The UK has always been one of the most important security providers at the EU level, and any post-Brexit arrangement will have to make sure this absence does not translate into an enhanced security issue for both sides.

It is conventional wisdom - a bit out-fashioned perhaps that foreign policy, intelligence and external/military security are related to 'sovereign' activities; they are notionally quite clearly distinguishable from the areas of domestic security and law enforcement. So, it should be distinguishable, in parallel, 'military' matters and 'enemy' threats from 'police' matters and 'criminal' threats. Another clear distinction should be the one between 'national' interests and 'non-national' ones (including supranational, transnational and international). However, the times of such a clear-cut, 'Westphalian' simplified reading of the world are long gone. In the twenty-first century's global environment, the EU matters at large, and the very 'Brexit and security' discourses, seem to be overall characterised by fuzzier categories and multiple and diverse tensions.

Said tensions are generated by the interaction of different sets of old-fashioned polarities (foreign vs. domestic, enemy vs. criminal, etc.), in addition to emerging hybrid elements between 'classic' polar ones (most prominently, the hybrid threat of international terrorism, or that of transnational organised crime), all combining together in a complex picture with very little black or white elements, and certainly more than fifty shades of grey. 
The EU institutional environment is also complex.

Several overlapping sets of EU-centred agencies and arrangements deal with security on the European continent, some including all the EU members, others that exclude some Member state(s) due to various opt-outs having been implemented (Denmark, Ireland and the UK, with respect to the Area of Freedom, Security and Justice). Finally, a few others do include third-party states due to specific arrangements between them and the EU (e.g. Norway, Switzerland, Iceland and Liechtenstein all participate in Schengen arrangements, including the Schengen Information System).

This has clearly been the result of a delicate balancing exercise conducted by 28 Member state(s), in addition to some non-members, to enjoy the benefits of cooperation without crossing some kind of individual, and domestically dictated, political and/or constitutional red line. The imperfect consistency of this complex system of sometimes seemingly overlapping arrangements and agencies is, thus, what, to some extent, made the system possible in the first place.

One of the obvious difficulties of integrating Member state(s)' national security and the EU apparatus lies indeed in the complexity of the EU structure. This has always been a well-known issue, complicated by the diverse characteristics and roles of the various EU agencies:

In the alphabet soup of bodies that you mention here, there is a slight mix-up between bodies which are essentially for policy formulation, like the terrorist working group and the counter-terrorism group, and the CTG, which has a much more operational structure. ${ }^{1}$

As facts have proved, in the EU Member state(s), external terrorist threats and attacks (Madrid, 2004, London, 2006 and Paris, 2017) have worked as a collider, bridging external 
and internal security mechanisms and pushing strongly for enhanced information sharing and cross-country cooperation.

For what concerns criminal matters and law enforcement, the sector had first been reshaped in 1993 with the definition of the so-called 'Third Pillar', which included policies of police and judicial cooperation at the intergovernmental level amongst the Member state(s).

Later on, with the entry into force of the Lisbon Treaty, the 'Pillars' system has been superseded by an enhanced concept: that of 'Space', with an Area of Freedom, Security and Justice (AFSJ) offered by the Union to its citizens - as introduced in article 1(5) of the Amsterdam Treaty and later enshrined in article 3(2) TEU, and better specified in Title V (arts. 67 to 89) of the Treaty on the Functioning of the European Union (TFEU).

At the same time, some of the EU Member state(s) negotiated their limited or nil participation to the AFSJ, in consideration of their legal traditions and political and constitutional constraints: Denmark opted out of the Third Pillar under the Treaty of Amsterdam. A subsequent selective opt-in for Denmark in relation to specific measures in the AFSJ, negotiated along with the Treaty of Lisbon, has been rejected by Danish voters in a referendum held in December 2015.

Ireland and the UK negotiated opt-outs from the Justice and Home Affairs Council (JHA) under the Treaty of Amsterdam, subsequently transferred in the Treaty of Lisbon AFSJ, as defined in the Protocols attached to the TFEU. The option out has later been acted upon by the UK in July 2013, effective December 2014, before the entry into force of the European Court of Justice jurisdiction on matters related to Title $\mathrm{V}$ of the TFEU, with the subsequent re-opt-ins of the UK for selected arrangements of European cooperation related to the AFSJ.

Despite the mentioned opt-outs, the Lisbon impetus in developing the AFSJ had meant the EU reaching out for cooperation, approaching international organisations and third 
countries in the areas of security, law enforcement and justice as it was often the case with EUROPOL's operations. Less-thanfull access to facilities and benefits for non-participants to the AFSJ (whether EU Member state(s) or not) is made possible by special arrangements, bilateral schemes or access granted on a case-by-case basis option in for Ireland and the UK.

The aim of this short monograph is to explore what Brexit may possibly mean in terms of both the UK and European security, in the distinct albeit closely related fields of information sharing and intelligence cooperation, on one side, and law enforcement and crime prevention, on the other. Brexit consequences on either side of the Channel may probably not reach the same level of severity in those two fields, due to the quite different way the mechanics of cooperation work in the relevant areas - possibly causing a few problems in the latter, at least.

\subsection{THE GENERAL CONTEXT OF EUROPEAN SECURITY. SHORT NOTES ON EUROPEAN DEFENCE COOPERATION}

Before going into a detailed analysis of the subject of this study (internal security in terms of intelligence sharing and law enforcement across the EU), it is appropriate to offer a brief outlook of the overall EU security framework and the way it has been constructed over the decade. This is because, whilst not constituting itself an object of analysis, it provides the general context all security discourses in the EU, external and internal, have to come to terms with.

Any discussion of the European defence and general military security must start with NATO. This is because the NATO umbrella has historically been always present and relevant, for the non-EU countries (Iceland, Norway and Turkey) 
as well as for the EU ones, and for the UK as well. Even Denmark, who has kept self-exclusion from all EU military arrangements, has been a NATO member since its origin in 1949 - if, initially, in a formally limited one under the conditions of no NATO bases, no nuclear warheads and no NATO activities on the Danish soil. ${ }^{2}$

The Western European Union (WEU) was founded before NATO, in 1948 amongst France, the UK and Benelux countries, originally in a defensive key vis-à-vis a possible German resurgence, with a wide socio-cultural, economic and defence mission; it later reduced its scope of activities to common defence and economic matters only with the enlargement of 1954, when Germany and Italy were admitted. The WEU mission was then further reduced to defence matters only, as the EU and the Council of Europe eroded its original area of competence; Spain, Portugal (1990) and Greece (1995) later joined the alliance. ${ }^{3}$

Compared with the NATO, the WEU has been a much less dynamic international military organisation. An important political bridging role has been played by the WEU after 1954, through confidence-building cooperation and consultations in the area of armaments control, in the solution of the Saar issue, and eventually contributing to the admission of Germany in the NATO and to the UK's accession to the EU in $1973 .{ }^{4}$

After 1973, the WEU became more or less inoperative, as the Western European defence responsibilities were discharged by NATO, very much in line with the UK's traditional opposition to the developing of European autonomous defence capabilities.

Initiatives to reactivate the WEU were taken in the mid-1980s, in a fast-changing world setting, with WEU Conferences in Rome (1984) and The Hague (1987): fundamental principles have been established there on developing a European 
Security and Defence Identity (ESDI), and enhanced security and defence roles of the WEU within, and identified with, the European Community and the coming EU, as the European pillar of the Atlantic Alliance. ${ }^{5}$ The need to develop the ESDI within the NATO, with reinforcement of the trans-Atlantic link and full cooperation between NATO and the WEU was subsequently stated at the Ministerial Meeting of the North Atlantic Council of May-June 1996 in Berlin. ${ }^{6}$

The Treaty of Maastricht included the vision of European military institutions, and an obligation for Member state(s) of the EU to join the WEU, as part of this vision. A first Danish referendum after Maastricht returned a rejection of the Treaty, which compelled the EU to grant Denmark four opt-outs negotiated in 1992 at Edinburgh: from WEU membership, European Monetary Union, European citizenship and JHA/third pillar cooperative measures, before a second Danish referendum in 1993 permitted the ratification of the Treaty and, thus, its entry into force in the entire EU. The Danish exclusion from defence matters has later been confirmed with an opt-out in Protocol 22 to the Treaty of Amsterdam excluding the Danish Kingdom from the EU Common Security and Defence Policy.

The WEU, at its final stage, had a kernel of 10 NATO and EU Member state(s). Between 1992 and 1994, a number of non-EU NATO Member state(s) joined the WEU as Associate Members (Turkey, Iceland and Norway); a number of nonNATO, EU members did so as Observers (Austria, Ireland, Sweden and Finland), as well as Denmark, belonging both to the EU and NATO (but with an opt-out from the EU's Common Security and Defence Policy (CSDP)); and a number of non-NATO, non-EU became WEU's Associate Partners (Bulgaria, Romania, Slovakia, Slovenia and the Baltic States, which all eventually joined both NATO and the EU) - somehow reflecting the inclination (or necessity) of the EU towards including a high number of members accorded a wide range 